\title{
Strong coast-ocean and surface-depth gradients in prokaryotic assemblage structure and activity in a coastal transition zone region
}

\author{
Federico Baltar ${ }^{1, *}$, Javier Arístegui ${ }^{1}$, Josep M. Gasol ${ }^{2}$, Santiago Hernández-León ${ }^{1}$, \\ Gerhard J. Herndl ${ }^{3}$ \\ ${ }^{1}$ Facultad de Ciencias del Mar, Universidad de Las Palmas de Gran Canaria, Campus Universitario de Tafira, \\ 35017 Las Palmas de Gran Canaria, Spain \\ ${ }^{2}$ Departament de Biologia Marina i Oceanografia, Institut de Ciències del Mar - CSIC, Pg. Marítim de la Barceloneta 37-49, \\ 08003 Barcelona, Spain \\ ${ }^{3}$ Department of Biological Oceanography, Royal Netherlands Institute for Sea Research (NIOZ), PO Box 59, 1790 AB, \\ Den Burg, The Netherlands
}

\begin{abstract}
The distribution of marine Crenarchaeota Group I, marine Euryarchaeota Group II and some major groups of Bacteria (SAR 11, Roseobacter, Gammaproteobacteria and Bacteroidetes) was investigated in the North Atlantic water column (surface to $2000 \mathrm{~m}$ depth) along a transect from the coastal waters of the NW African upwelling to the offshore waters of the Canary Coastal Transition Zone (CTZ). Catalyzed reporter deposition-fluorescence in situ hybridization (CARD-FISH) was used to describe the prokaryotic assemblages. Bulk picoplankton abundance and leucine incorporation were determined. Pronounced changes in prokaryotic assemblage composition were observed from the coast to the open ocean and at the deep chlorophyll maximum (DCM) with decreasing bulk heterotrophic activity. All bacterial groups decreased in absolute abundances from the coast to the open ocean; both archaeal groups increased towards the open ocean. Prokaryotic abundance and activity decreased 2 and 3 orders of magnitude, respectively, from the surface to $2000 \mathrm{~m}$. Prokaryotic growth rates were high in the mesopelagic zone $\left(\sim 0.13 \mathrm{~d}^{-1}\right)$, compared to other reports from the central North Atlantic. SAR11 in total picoplankton abundance decreased from $42 \%$ in the DCM to $4 \%$ at $2000 \mathrm{~m}$, while marine Crenarchaeota Group I increased from $1 \%$ in the DCM to $39 \%$ in the oxygen minimum layer. A clear influence of the different intermediate water masses was observed on the bulk heterotrophic picoplankton activity, with lower leucine incorporation rates corresponding to layers where patches of Antarctic Intermediate Water were detected. Coast-ocean and surface-depth gradients in bulk prokaryotic abundance and production and assemblage composition were comparable to changes observed in basin-scale studies, pinpointing the CTZs as regions of strong variability in microbial diversity and metabolism.
\end{abstract}

KEY WORDS: Archaea $\cdot$ Bacteria $\cdot$ Assemblage structure $\cdot$ Activity $\cdot$ Deep ocean $\cdot$ CARD-FISH Resale or republication not permitted without written consent of the publisher

\section{INTRODUCTION}

Over the past few decades it has become clear that prokaryotes are an important component of marine plankton communities, playing a key role in mediating a range of biogeochemical cycles (Azam et al. 1982). Prokaryotic plankton have been enumerated in a 'black-box' approach, firmly establishing that they represent the largest pool of living biomass in the sea (Gasol et al. 1997). With the advent of molecular biology techniques, marine microbiologists have been able to analyze the prokaryotic communities from a 'Gleasonian' point of view (Gleason 1926), focusing on distinct prokaryotic groups that can be reliably identified and quantified in marine assemblages. 
Small-subunit ribosomal RNA (rRNA) genes, analyzed by molecular techniques, have become the universal phylogenetic markers and the main criteria by which microbial plankton groups are identified (Giovannoni \& Rappé 2000). Most of these groups were first identified by sequencing 16S rRNA genes cloned from seawater (e.g. Giovannoni et al. 1990). It soon became apparent that $<20$ microbial clades accounted for most of the genes recovered (Mullins et al. 1995). Nevertheless, 16S rRNA gene-clone libraries do not accurately reflect the abundance of microbes from particular phylogenetic clades in the environment. Such analyses need to be complemented by other strategies aimed at studying single populations in situ. Hybridization techniques such as catalyzed reporter deposition-fluorescence in situ hybridization (CARD-FISH; Pernthaler et al. 2002) became an indispensable tool in determining the abundance of specific prokaryotic groups in the natural environment. Indeed, some groups of marine bacteria had been known for years from their 16S rRNA gene sequences before their abundances could be determined. Paradigmatic examples are bacteria related to the marine SAR11 (Morris et al. 2002), SAR86 (Pernthaler et al. 2002), SAR116 (Fuchs et al. 2005), SAR202 (Morris et al. 2004), or the SAR406 (Fuchs et al. 2005) clades.

The presence of planktonic prokaryotes in a given oceanic habitat is thought to be determined by local environmental conditions and not by restricted dispersal (Pedrós-Alió 2006). Members of the SAR11 clade are among the most common prokaryotes in the marine plankton. They can contribute $>50 \%$ to the total picoplankton abundance in the surface waters of the northwestern Sargasso Sea, and $25 \%$ of mesopelagic picoplankton assemblages (Morris et al. 2002). Bacteria related to Roseobacter, also referred to as the SAR83 cluster (Rappe et al. 2000), are another common component of coastal and offshore picoplankton assemblages constituting up to $25 \%$ of marine picoplankton (González \& Moran 1997, Eilers et al. 2001). The seasonal dynamics in the abundance of Roseobacter closely follows the development of phytoplankton biomass in the North Sea (Eilers et al. 2001). Furthermore, it has been shown that members of these 2 clades (SAR11 and Roseobacter) efficiently utilize dimethylsulfoniopropionate (Malmstrom et al. 2004a,b). The Bacteroidetes cluster has been associated with upwelling events (Fandino et al. 2001, Alonso-Sáez et al. 2007b), and members show a high ability to degrade high-molecular-weight compounds (Cottrell \& Kirchman 2000). Members of the SAR86 lineage, related to the Gammaproteobacteria, are characterized by high growth rates, probably efficiently exploiting nutrient pulses (Eilers et al. 2000).
Archaea are widespread among marine prokaryotic plankton (De Long et al. 1994, Massana et al. 1998). Quantitative studies using FISH have shown the dominance of Crenarchaeota in meso- and bathypelagic waters, whereas Euryarchaeota were thought to comprise less than 5 to $8 \%$ of total picoplankton abundance in deep waters of the Pacific and the Antarctic Oceans (Karner et al. 2001, Church et al. 2003). Using CARD-FISH, in combination with the Proteinase-K permeabilization of the archaeal cell wall, Teira et al. (2004, 2006a,b) and Herndl et al. (2005) found higher (10 to $20 \%$ ) abundances of Euryarchaeota in deep waters of the North Atlantic Ocean than reported by Karner et al. (2001) for the subtropical North Pacific Gyres. All these studies support the view that diverse prokaryotic groups are linked to different environmental conditions and, hence, changes in assemblage structure are likely to be more pronounced in regions with strong oceanographic gradients.

Most of the studies describing variability in the composition of picoplankton have been carried out in surface oceanic waters (e.g. Alonso-Sáez et al. 2007b). Only a few have quantified the different groups of prokaryotes in the dark ocean. Among these, some studies used PCR-based fingerprinting techniques (Hewson et al. 2006) to identify components of the prokaryotic community, while others applied PCRindependent group-level FISH. The latter, however, have used 2 or 3 prokaryotic probes targeting Bacteria, Crenarchaeota and Euryarchaeota (Karner et al. 2001, Teira et al. 2004, 2006b, Herndl et al. 2005). Information regarding the activity of deep-water prokaryotic communities is rather scarce compared to that of surface-water prokaryotic assemblages (Reinthaler et al. 2006). Measurements on depressurized samples indicate a decrease in picoplankton production of 1 to 2 orders of magnitude from the euphotic zone to the bathypelagic waters (Reinthaler et al. 2006), declining with depth slightly more than picoplankton abundance.

Variations in bulk prokaryotic activity may be related to changes in the abundance of specific groups. Some studies have shown a clear link between the distribution of the major prokaryotic groups to bulk (Massana et al. 1998) and group-specific prokaryotic activity in the dark ocean (Teira et al. 2004, 2006b, Herndl et al. 2005). This relationship might be more evident in regions with strong environmental gradients and relatively high picoplankton activity. Arístegui et al. (2005) measured high prokaryotic activities in the mesopelagic waters of the subtropical NE Atlantic, a region characterized by strong hydrological variability, with most pronounced gradients close to the NW African coastal upwelling (Arístegui et al. 2003).

In the present study, we report the distribution of both the bulk prokaryotic activity and the abundance 
of major prokaryotic groups (marine Crenarchaeota Group I, marine Euryarchaeota Group II, SAR 11, Roseobacter, Gammaproteobacteria and Bacteroidetes) along a transect from the coastal waters of the NW African upwelling to the offshore waters of the Canary region. We used CARD-FISH to determine the composition of the prokaryotic community and relate it to bulk leucine incorporation. We hypothesized that the contribution of marine Crenarchaeota Group I and marine Euryarchaeota Group II to total picoplankton abundance increases along the coast-ocean transect in the mesopelagic waters and, overall, that the surface-depth patterns of abundance and metabolism of Bacteria and Archaea are related to local hydrographic conditions.

\section{MATERIALS AND METHODS}

Location and sampling. A zonal section of 10 stations was sampled from the coastal waters of the NW Africa upwelling $\left(27.9^{\circ} \mathrm{N}, 13.1^{\circ} \mathrm{W}\right)$ to the offshore waters of the Canary Coastal Transition Zone (CTZ) region $\left(27.5^{\circ} \mathrm{N}, 15.3^{\circ} \mathrm{W}\right)$ (Fig. 1) during the CONAFRICA cruise (22 March to 7 April 2006) on board the RV 'Hespérides'. At each station, temperature, salinity and fluorescence were recorded down to $2000 \mathrm{~m}$ depth using a SeaBird 911 plus CTD system, mounted on a General Oceanics rosette sampler, equipped with twenty-four 121 Niskin bottles. Samples for prokaryotic heterotrophic production and abundance were collected at each station from 5 depths ranging from 5 to $2000 \mathrm{~m}$, including the deep chlorophyll maximum (DCM; 30 to $82 \mathrm{~m}), 200 \mathrm{~m}$ and the oxygen minimum zone (OMZ; 740 to $760 \mathrm{~m}$ ). Samples for CARD-FISH were only collected at 6 selected stations and at 3 depths (DCM, OMZ and $2000 \mathrm{~m}$ ).

Prokaryotic abundance and biomass. Prokaryotic abundance was determined by flow cytometry (FCM) using a FACSCalibur (Becton Dickinson) with a laser emitting at $488 \mathrm{~nm}$ wavelength. Samples $(1.5 \mathrm{ml})$ were fixed with paraformaldehyde (1\% final concentration), incubated at $4^{\circ} \mathrm{C}$ for 15 to $30 \mathrm{~min}$ and then stored frozen in liquid nitrogen until analysis. Prior to counting the cells by FCM, $200 \mu$ of sample was stained with a DMS-diluted SYTO-13 (Molecular Probes) stock (10:1) at $2.5 \mu \mathrm{M}$ final concentration. Prokaryotes were identified by their signatures in a plot of side scatter (SSC) versus green fluorescence (FL1). High and low nucleic acid cells (H1-NA, H2-NA, L-NA) were separated in the scatter plot (Gasol et al. 1999). H1-NA cells exhibited slightly lower SSC and higher FL1 than L-NA cells. H2-NA cells showed high SSC and high FL1 (see Fig. 2). Picocyanobacteria were discriminated in a plot of FL1 versus red fluorescence (FL3). When the fluorescence signal of the prochlorophytes was very low, they were first enumerated in an unstained sample and their abundance subtracted from the total prokaryotic abundance determined by SYTO-13 staining. Prokaryotic carbon biomass was estimated from prokaryotic abundance assuming a conversion factor of $12 \mathrm{fg} \mathrm{C}^{\mathrm{C}} \mathrm{cell}^{-1}$ (Fukuda et al. 1998). A suspension of yellow-green $1 \mu \mathrm{m}$ latex beads $\left(10^{6}\right.$ beads $\left.\mathrm{ml}^{-1}\right)$ was added as an internal standard (Polysciences). The concentration of beads was determined under an epifluorescence microscope. Overall, picoplankton abundance determined by FCM and by DAPI staining and epifluorescence microscopy gave very similar abundance values (FCM $=0.99 \times$ DAPI $\left.-0.226, \mathrm{R}^{2}=0.84, \mathrm{p}<0.001, \mathrm{n}=14\right)$.
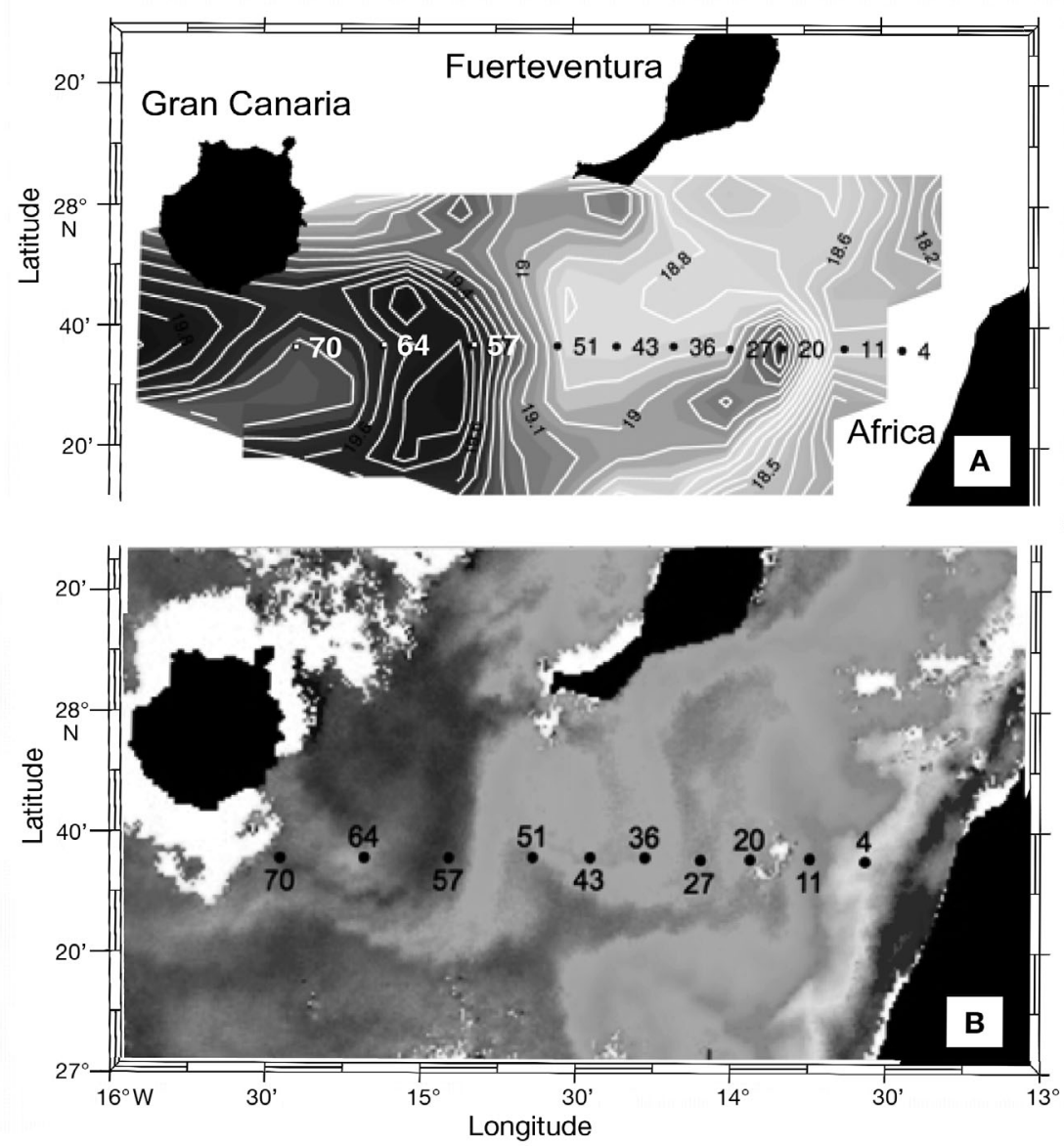

Fig. 1. (A) Near sea-surface temperature, and (B) Sea-viewing Wide Field-of-view Sensor (SeaWiFS) chlorophyll image from 7 April 2006. Station positions (4 to 70 ) overlaid on maps. Note the upwelling filament extending offshore from the coast 


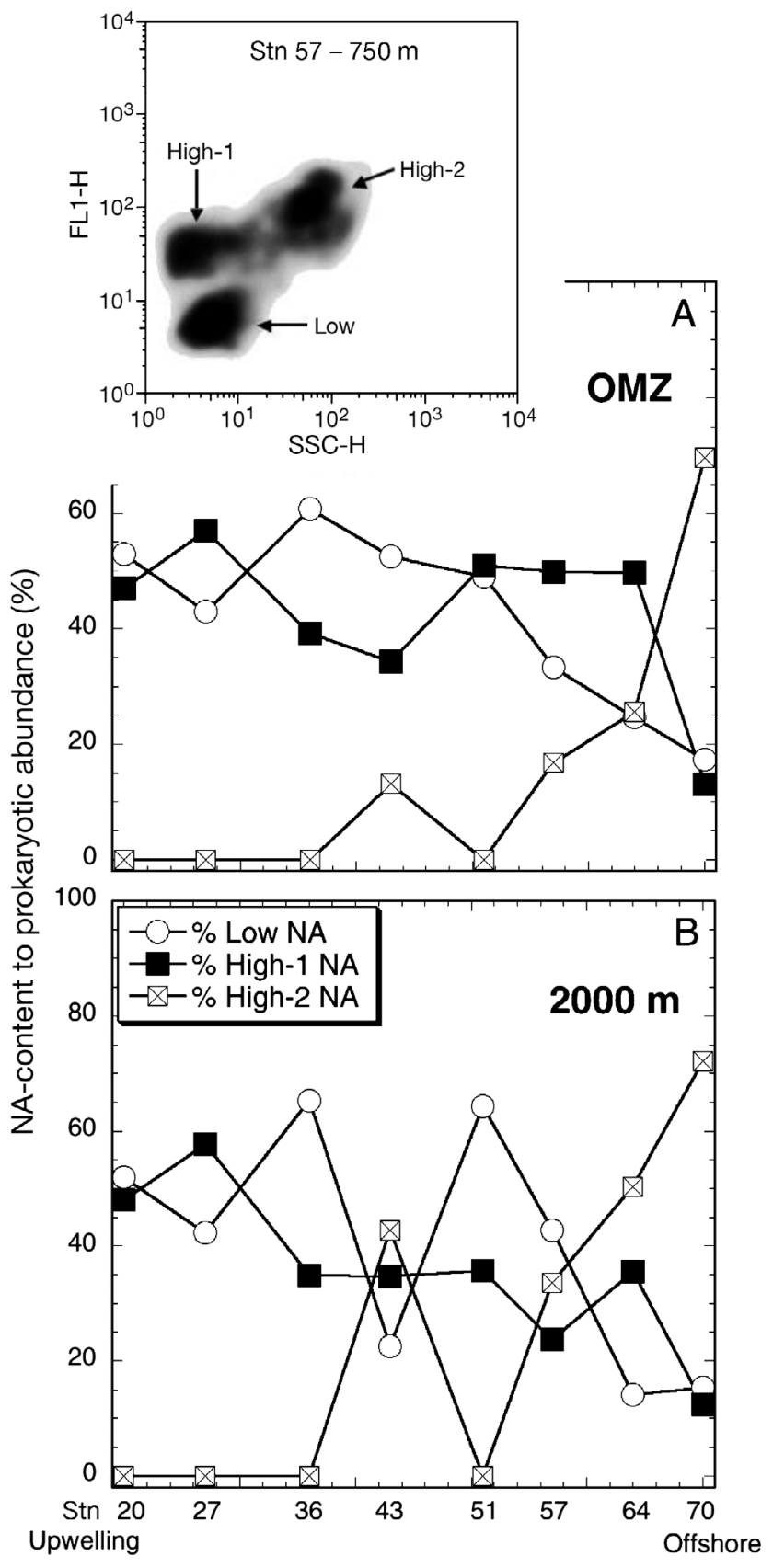

Fig. 2. Abundance of low and high nucleic-acid (NA) content cells as percentage of total prokaryotic abundance, at (A) the oxygen minimum zone (OMZ), and (B) $2000 \mathrm{~m}$ depth. The inset in (A) shows the 3 prokaryotic populations (Low, High-1 and High-2) according to their size (side scatter; SSC-H) and NA content (green fluorescence; FL1-H)

Prokaryotic heterotrophic production. Prokaryotic heterotrophic production was estimated from the rates of protein synthesis determined by the incorporation of tritiated leucine using the centrifugation method (Smith \& Azam 1992). ${ }^{3} \mathrm{H}$-Leucine (Leu, Amersham, specific activity $=171 \mathrm{Ci} \mathrm{mmol}^{-1}$ ) was added at saturat- ing concentration $\left(40 \mathrm{nmol}^{-1}\right)$ to 4 replicate subsamples of $1.2 \mathrm{ml}$. Duplicate controls were established by adding $120 \mu \mathrm{l}$ of $50 \%$ trichloroacetic acid (TCA) $10 \mathrm{~min}$ prior to isotope addition. The Eppendorf tubes were incubated at in situ temperature in temperaturecontrolled chambers for 2 to $7 \mathrm{~h}$. Incorporation of leucine in the quadruplicate sample was stopped by adding $120 \mu \mathrm{l}$ ice-cold $50 \%$ TCA. Subsequently, the subsamples and the controls were kept at $-20^{\circ} \mathrm{C}$ until centrifugation (at ca. $12000 \times g$ ) for $20 \mathrm{~min}$, followed by aspiration of the water. Finally, $1 \mathrm{ml}$ of scintillation cocktail was added to the Eppendorf tubes before determining the incorporated radioactivity after 24 to $48 \mathrm{~h}$ on a Wallac scintillation counter with quenching correction using an external standard. Leucine incorporated into prokaryotic biomass was converted to carbon production using the theoretical conversion factor of $1.5 \mathrm{~kg} \mathrm{C} \mathrm{mol}^{-1}$ Leu assuming no isotope dilution (Simon \& Azam 1989). Since both Bacteria and Archaea incorporate leucine, it is more appropriate to refer to the term 'prokaryotic heterotrophic production' instead of the commonly used 'bacterial production' (Herndl et al. 2005).

CARD-FISH. Immediately after collecting the samples from the Niskin bottles, 10 to $40 \mathrm{ml}$ subsamples were fixed with paraformaldehyde ( $2 \%$ final concentration) and stored at $4{ }^{\circ} \mathrm{C}$ in the dark for 12 to $18 \mathrm{~h}$. The cells were collected on a $0.2 \mu \mathrm{m}$ polycarbonate filter (Millipore, GTTP, $25 \mathrm{~mm}$ filter diameter) supported by a cellulose nitrate filter (Millipore, HAWP, $0.45 \mu \mathrm{m}$ ), washed twice with $0.2 \mu \mathrm{m}$ filtered Milli-Q water, dried and stored in a microfuge vial at $-20^{\circ} \mathrm{C}$ until further processing in the laboratory. Filters for CARD-FISH were embedded in low-gelling-point agarose and incubated either with lysozyme for the Bacteria probes Eub338-III (mixture of probes Eub338, Eub II and Eub III; Amann et al. 1990, Daims et al. 1999), for Roseobacter using Ros537 (Eilers et al. 2001), for Gammaproteobacteria Gam42a (Manz et al. 1992), for Bacteroidetes CF319a (Amann et al. 1990) and for SAR11 using SAR11-441R (Morris et al. 2002), or Proteinase-K for the marine Euryarchaeota Group II probe Eury806 and for the marine Crenarchaeota Group I probe Cren537 (Teira et al. 2004). Filters were cut in sections and hybridized with horseradish peroxidase (HRP)labeled oligonucleotide probes and tyramide-Alexa 488 for signal amplification, following the protocol described in Teira et al. (2004). Cells were counterstained with a DAPI mix: 5.5 parts Citifluor, 1 part Vectashield (Vector Laboratories) and 0.5 parts phosphate-buffered saline (PBS) with DAPI (final concentration $1 \mu \mathrm{g} \mathrm{ml}^{-1}$ ). The slides were examined under a Zeiss Axioplan 2 microscope equipped with a $100 \mathrm{~W}$ Hg lamp and appropriate filter sets for DAPI and Alexa488. More than 800 DAPI-stained cells were 
counted per sample in a minimum of 30 fields of view. For each microscopic field, 2 different categories were enumerated: (1) total DAPI-stained cells, (2) cells stained with the specific probe. The counting error, expressed as the percentage of the standard error between replicates, was $2 \%$ for DAPI counts.

\section{RESULTS}

\section{Regional oceanographic settings}

The stations were placed along a coast-ocean transect crossing an upwelling filament and an offshore anticyclonic eddy centered at Stn 57 (Fig. 1A). Filament-eddy systems have been described in previous studies for the same region (Barton et al. 2004). The eddy entrained filament-water with a higher chlorophyll content in a meandering fashion, giving rise to sharp fronts in chlorophyll and temperature. Fig. 1B (from 7 April 2006) illustrates the advection of high chlorophyll-containing water along the filament, coinciding with a low surface temperature field (Fig. 1A) recorded during the course of the study (22 March to
7 April 2006). Fig. 3A shows the vertical cross-section of density and chlorophyll concentrations. The DCM was located between 20 and $40 \mathrm{~m}$ depth near the upwelling region and deepened slightly towards the open ocean, with the most pronounced deepening of the DCM in the eddy center at Stn 57. The sharpest gradients in density and chlorophyll were found between Stns 11 and 20 (upwelling front), Stns 57 and 64 (eddy-filament front) and Stns 64 and 70 (eddy-open ocean water front).

The North Atlantic Central Water (NACW) occupied the main thermocline (Fig. 3B). Below the NACW, 2 intermediate water masses dominated the 600 to $1500 \mathrm{~m}$ depth range: the Antarctic Intermediate Water (AAIW) with its fresh anomaly values (salinity values <35.3), and the warm, high-salinity Mediterranean Sea Outflow Water (MSOW). The AAIW was manifested as tongues of lower-salinity water, centered at 750 to $900 \mathrm{~m}$ depth, in the eastern part of the section (Stns 20, 36 and 43; Fig. 3B). The AAIW is transported northward by a current wider than the usual alongshore poleward undercurrent (Hernández-Guerra et al. 2001). All stations from the western part of the section (Stns 70, 64, 57, 51) as well as Stn 27 were

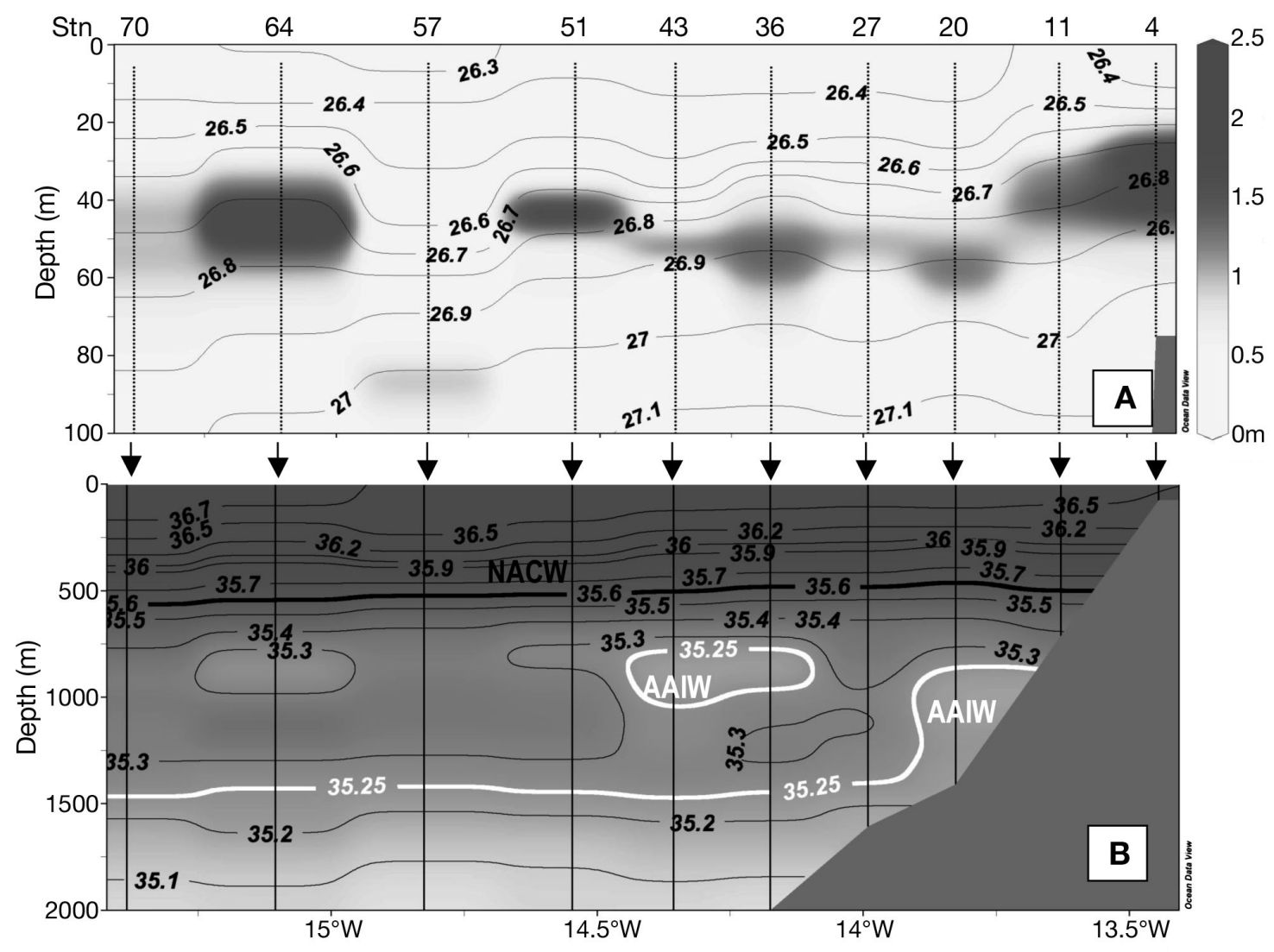

Fig. 3. (A) Potential density (kg m${ }^{-3}$, grey lines) and chlorophyll fluorescence (relative units, in grey scale), and (B) salinity. AAIW, Antarctic Intermediate Water; NACW, North Atlantic Central Water 


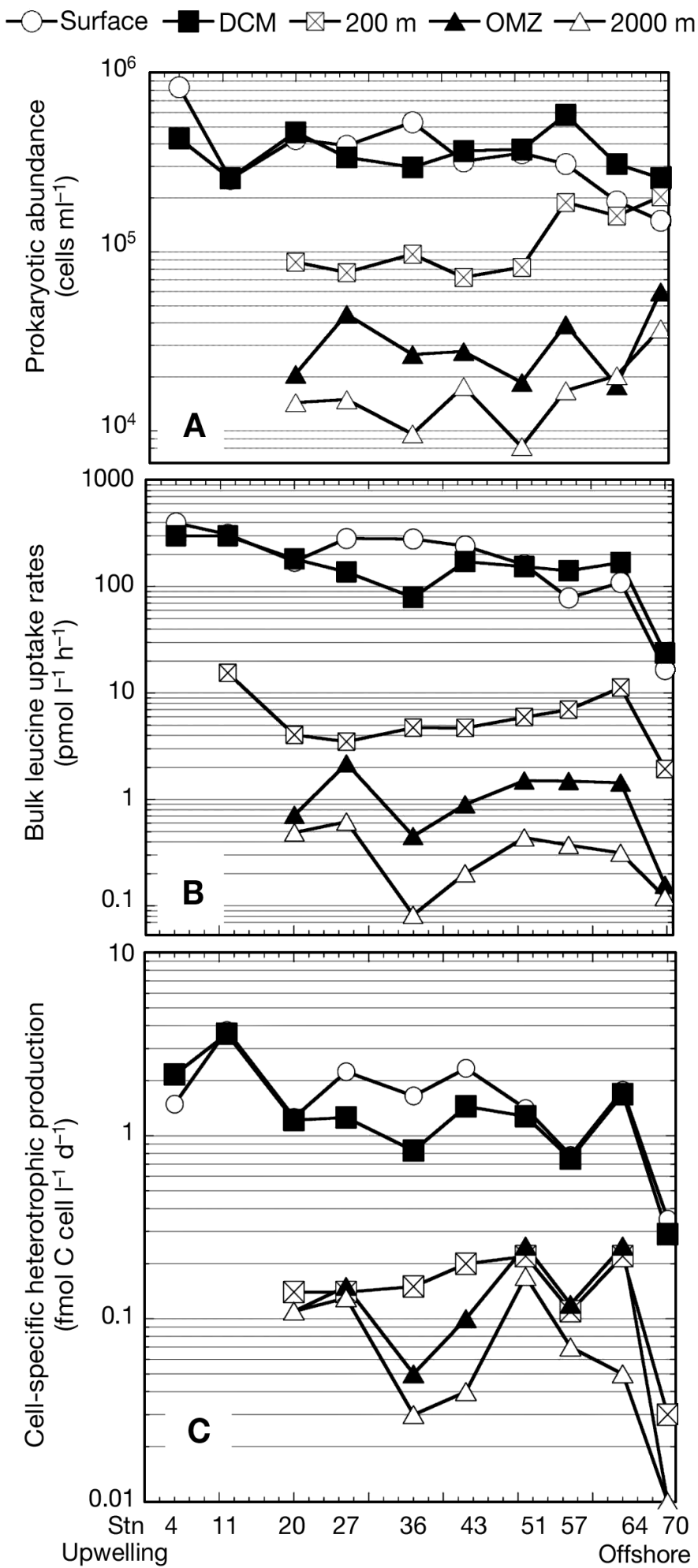

Fig. 4. (A) Prokaryotic abundance, (B) bulk leucine incorporation rates, and $(\mathrm{C})$ cell-specific heterotrophic production along the coast-offshore transect in the surface waters $(5 \mathrm{~m})$, deep chlorophyll maximum (DCM), $200 \mathrm{~m}$ depth, oxygen minimum zone (OMZ) and $2000 \mathrm{~m}$ depth. Standard errors are not visible since they are smaller than the symbols.

Note that the coastal stations have no deep samples dominated by MSOW. The water masses below the intermediate waters represented a mixture between North Atlantic Deep Water (NADW) and intermediate waters. The presence of the different hydrographic structures or water masses clearly influenced the distribution and activity of the prokaryotic community.

\section{Prokaryotic abundance and activity}

Generally, prokaryotic abundance in the surface waters and the DCM decreased from the upwelling region to the open ocean while for the $200 \mathrm{~m}$ depth horizon, the OMZ and the $2000 \mathrm{~m}$ depth horizon, no distinct lateral trend was detectable (Fig. 4A). Prokaryotic abundance in the surface and the DCM ranged from 1.5 to $8.3 \times 10^{5}$ cells $\mathrm{ml}^{-1}$, decreasing exponentially to 0.8 to $3.7 \times 10^{4}$ cells $\mathrm{ml}^{-1}$ at $2000 \mathrm{~m}$ depth (Fig. 4A).

Similar to prokaryotic abundance, leucine incorporation rates were highest in the surface waters and the DCM in the coastal upwelling region (398 pmol Leu $\mathrm{l}^{-1}$ $\mathrm{h}^{-1}$ ), decreasing more than 20 -fold towards the oceanic stations (16.7 pmol Leu $\mathrm{l}^{-1} \mathrm{~h}^{-1}$ ) and by 3 orders of magnitude with depth (Fig. 4B). The highest values of cellspecific production were also found at the stations close to the upwelling region in the surface and the DCM layer (3.8 and $3.6 \mathrm{fmol} \mathrm{C} \mathrm{cell}{ }^{-1} \mathrm{~d}^{-1}$, respectively), decreasing towards the open ocean stations (Stn 70: 0.3 fmol C cell ${ }^{-1} \mathrm{~d}^{-1}$ ) (Fig. 4C). Interestingly, leucine incorporation and cell-specific production followed a similar pattern in the OMZ and at $2000 \mathrm{~m}$ depth, albeit 1 order of magnitude lower than in the epipelagic zone (Fig. 4B,C). Cell-specific leucine incorporation between the $200 \mathrm{~m}$ layer and the OMZ was not significantly different (Student's $t$-test; $\mathrm{p}=0.24, \mathrm{n}=8$ ) (Table 1); however, it was only half at $2000 \mathrm{~m}$ depth (Table 1, Fig. 4C). The prokaryotic biomass turnover time (prokaryotic abundance divided by production; Kirchman 2002) increased with depth (from $<2 d$ in the surface

Table 1. Mean $( \pm \mathrm{SE})$ prokaryotic activity along the coast-offshore transect. CSHP: cell-specific heterotrophic production; PGR: prokaryotic growth rate; H-NA: high nucleic acid content prokaryotes; DCM: deep chlorophyll maximum; OMZ: oxygen minimum zone. Ten measurements were made at $5 \mathrm{~m}$ (surface) depth; 8 measurements were made at all other depths

\begin{tabular}{|lcccc|}
\hline Depth & $\begin{array}{c}\text { CSHP (fmol } \\
\text { C cell }\end{array}$ d $\left.^{-1}\right)$ & $\begin{array}{c}\text { PGR } \\
\left(\mathrm{d}^{-1}\right)\end{array}$ & $\begin{array}{c}\text { Turnover } \\
\text { time }(\mathrm{d})\end{array}$ & $\%$ H-NA \\
\hline $5 \mathrm{~m}$ & $1.71 \pm 0.30$ & $1.02 \pm 0.18$ & $1.4 \pm 0.4$ & $23 \pm 3$ \\
$\mathrm{DCM}$ & $1.45 \pm 0.29$ & $1.34 \pm 0.27$ & $1.1 \pm 0.3$ & $27.8 \pm 4$ \\
$200 \mathrm{~m}$ & $0.15 \pm 0.02$ & $0.14 \pm 0.02$ & $10.5 \pm 4$ & $36.6 \pm 4$ \\
OMZ & $0.13 \pm 0.03$ & $0.12 \pm 0.03$ & $24.9 \pm 15$ & $66.5 \pm 17$ \\
$2000 \mathrm{~m}$ & $0.08 \pm 0.02$ & $0.07 \pm 0.02$ & $30.2 \pm 12$ & $67.6 \pm 19$ \\
\hline
\end{tabular}


waters to $>30 \mathrm{~d}$ at $2000 \mathrm{~m}$ depth; Table 1 ). The longest turnover times were observed at Stn 70, where prokaryotic activity was very low at all depths but cell numbers were higher in the deeper layers compared to the other stations, coinciding with the presence of large prokaryotic populations with H-NA content (Fig. 2).

At this station, a pronounced decrease in the percentage of L-NA cells and in one of the groups of the H-NA (H1-NA) was observed compared to the same depth layer of other stations. This decrease in the percentage of L-NA coincided with the highest relative abundance of the other H-NA group (H2-NA). Remarkably, the percentage of the H2-NA cells was higher in the $2000 \mathrm{~m}$ layer than in the OMZ (Fig. 2). As a general pattern, the dynamics of the individual NA groups followed a similar trend in the OMZ and the $2000 \mathrm{~m}$ layer along the transect.

\section{Prokaryotic assemblage structure}

The recovery efficiency of the prokaryotic community measured using CARD-FISH, i.e. the sum of the relative abundance of Bacteria, Crenarchaeota and
Euryarchaeota, was $77 \pm 3 \%$ (mean $\pm \mathrm{SD}, \mathrm{n}=14$ ) of total DAPI-stainable cells. On average, Bacteria accounted for $54 \pm 2 \%(\mathrm{n}=6)$ in the DCM and $45 \pm 2 \%$ $(\mathrm{n}=8)$ at $2000 \mathrm{~m}$ depth of DAPI-stained cells.

Bacteria were relatively more abundant in the upwelling region and decreased in contribution to total prokaryotic abundance towards the oceanic stations, particularly in the layers between the DCM and the $\mathrm{OMZ}$, while the archaeal contribution increased towards the open ocean (Fig. 5). The most abundant prokaryotic group in the DCM was SAR11, with a relative contribution to total DAPI-stainable cells ranging from 36 to $42 \%$ (Fig. 5). In the OMZ, the relative contribution of marine Crenarchaeota Group I and Bacteroidetes increased from the upwelling region towards the open ocean, while the contribution of SAR11 decreased and marine Euryarchaeota Group II and Roseobacter remained almost invariant along the transect (Fig. 5). The abundance of SAR11 declined steeply with depth, reaching the lowest relative abundance at $2000 \mathrm{~m}$ depth (Fig. 5). Marine Crenarchaeota Group I showed a contrasting trend with a low relative contribution in the DCM and the highest relative abundance in deep waters, where they accounted for

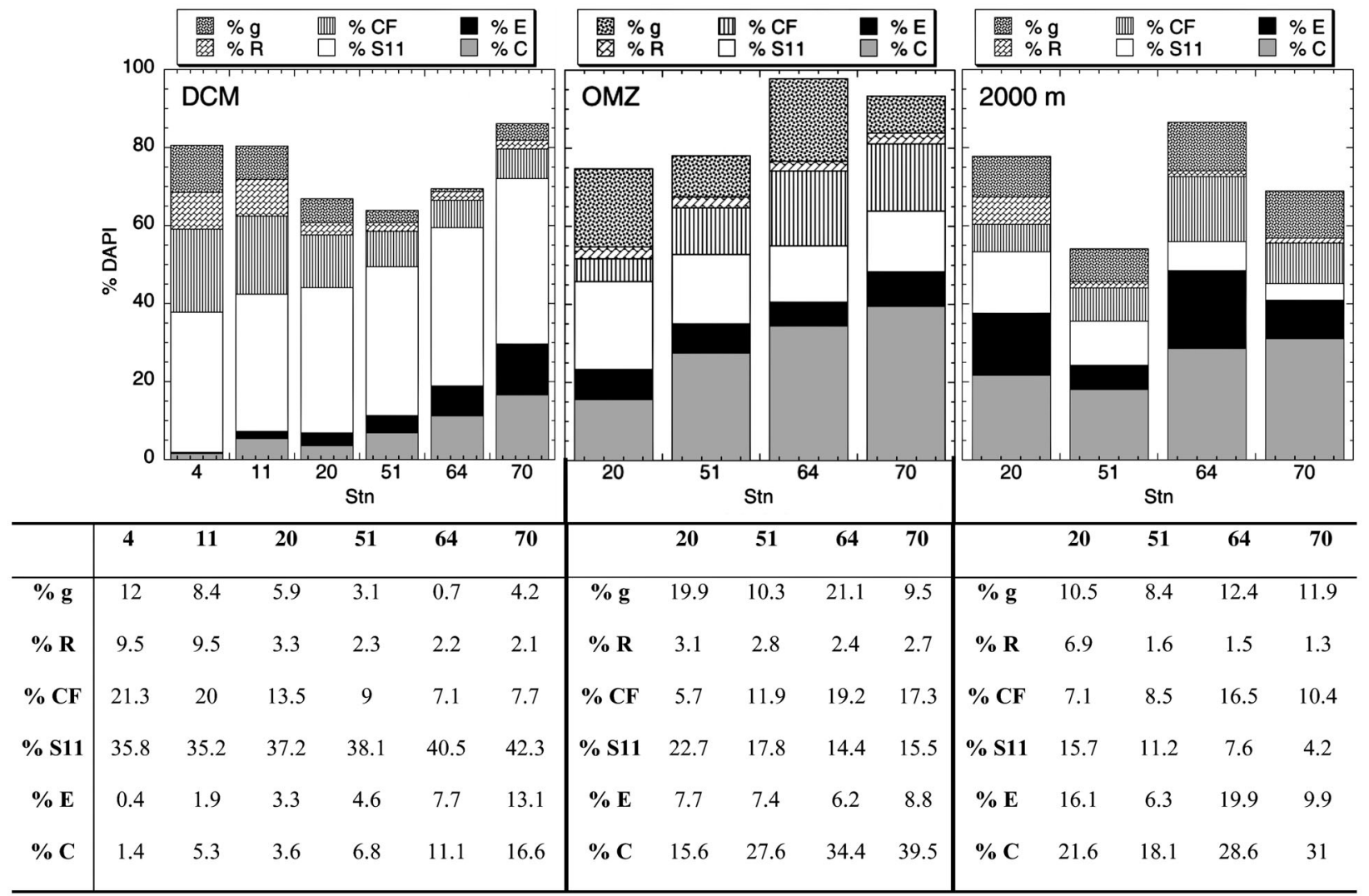

Fig. 5. Relative abundances of prokaryotic groups detected by horseradish peroxidase-oligonucleotide probes and CARD-FISH scaled to DAPI counts at the deep chlorophyll maximum (DCM), the oxygen minimum zone (OMZ) and at $2000 \mathrm{~m}$ depth. C: Marine Crenarchaeota Group I; E: marine Euryarchaeota Group II; S11: SAR11; CF: Bacteroidetes; R: Roseobacter; g: Gammaproteobacteria 
up to $39.5 \%$ of the DAPI-stained cells. The highest abundance of marine Crenarchaeota Group I, Bacteroidetes (with the exception of Stn 20) and Gammaproteobacteria were found in the OMZ. Marine Euryarchaeota Group II contributed up to 13 and $20 \%$ to the DAPI-stained cells in the DCM and $2000 \mathrm{~m}$ depth layer, respectively, without a clear vertical distribution pattern. Roseobacter, however, exhibited highest relative abundance in the DCM, particularly in the upwelling region, and lowest in the deep waters.

\section{DISCUSSION}

\section{Variability in bulk prokaryotic abundance and heterotrophic production}

The range of variability in leucine incorporation rates (16.7 to 398 pmol Leu $\mathrm{l}^{-1} \mathrm{~h}^{-1}$ ) measured in the surface waters along the coast-ocean transect (13 to $\left.15.3^{\circ} \mathrm{W}\right)$ was similar to other studies covering much larger spatial scales. For instance, Alonso-Sáez et al. (2007a) found leucine incorporation rates from 15 to $331 \mathrm{pmol}$ Leu $\mathrm{l}^{-1} \mathrm{~h}^{-1}$ in the eastern boundary region of the North Atlantic Ocean (14.5 to $26^{\circ} \mathrm{W}$ ), and Hoppe et al. (2006) reported a range of 2 to $141 \mathrm{pmol} \mathrm{Leu} \mathrm{l}^{-1} \mathrm{~h}^{-1}$ along a meridional transect across the central Atlantic Ocean $\left(53^{\circ} \mathrm{N}\right.$ to $\left.65^{\circ} \mathrm{S}\right)$. The highest prokaryotic activities in the present study were measured in the upwelling stations (Fig. 4B), while the lowest activities were measured in the most oceanic station. Leucine incorporation at the $200 \mathrm{~m}$ depth horizon was highest in the upwelling region and decreased to Stn 20, remarkably increasing thereafter towards Stn 64 (Fig. 4B), probably reflecting the accumulation of organic matter in the core of the anticyclonic eddy. Arístegui et al. (2003) observed large accumulations of dissolved organic carbon in the center of anticyclonic eddies in this region.

The most pronounced changes in the incorporation rate of leucine and cell-specific production were the decrease observed from Stn 64 to Stn 70 (Fig. 4B,C). In contrast, prokaryotic abundance did not decrease significantly (in the DCM), or it increased (in the OMZ and at $2000 \mathrm{~m}$ depth) (Fig. 4A). As indicated in Fig. 1, Stn 64 is located within the offshore extension of the filament while Stn 70 represents open ocean waters. Arístegui \& Montero (2005) reported high abundance of prokaryotes in the epipelagic zone at frontal regions between filaments and eddies. In their study, an increase in prokaryotic abundance was noticed at the $200 \mathrm{~m}$ depth horizon and deeper, but not in shallower waters. Excursions of isopycnals down to $800 \mathrm{~m}$ depth in eddy-pair fronts have been reported previously (e.g. Arístegui et al. 2003). This would explain the high abundance of prokaryotes at Stn 70, although surprisingly, this increase is observed even at $2000 \mathrm{~m}$ depth (Fig. 4A). None of the prokaryotic groups enumerated by CARD-FISH seemed to contribute specifically to this increase in prokaryotic abundance. However, it is evident that large cells with H-NA content contributed to the increase in prokaryotic abundance in the OMZ and $2000 \mathrm{~m}$ depth (Fig. 2).

These patterns may be related to the differences in the water masses. In intermediate waters such as the OMZ, prokaryotic activity was lower in the AAIW than in the MSOW, except at Stn 70, which exhibited the lowest prokaryotic activity in almost all depth layers. The lower activity in the AAIW is presumably the result of lower (or more refractory) organic carbon concentrations in this old water mass. At $2000 \mathrm{~m}$ depth, the prokaryotic activity pattern paralleled that of the $\mathrm{OMZ}$, suggesting mixing of the NADW with the intermediate waters (Fig. 4B).

Cell-specific prokaryotic production in surface waters was about 1 order of magnitude higher than in deep waters (Table 1), resulting in an average prokaryotic growth rate of $1.0 \pm 0.2 \mathrm{~d}^{-1}$ for surface waters. Our growth rates are substantially higher than the $0.4 \pm 0.1 \mathrm{~d}^{-1}$ reported by Arístegui et al. (2005) for the Canary Current region using the same approach as in the present study, although their stations were more oceanic. For Stn 70, the most oceanic station occupied in the present study, prokaryotic growth rate in surface waters was $0.26 \mathrm{~d}^{-1}$, comparable to those reported by Arístegui et al. (2005).

The average cell-specific prokaryotic production in the mesopelagic $\left(\sim 0.14 \mathrm{fmol} \mathrm{C}\right.$ cell $\left.{ }^{-1} \mathrm{~d}^{-1}\right)$ and bathypelagic (0.08 fmol C cell $\left.{ }^{-1} \mathrm{~d}^{-1}\right)$ zones is considerably higher than the range of 0.01 to $0.06 \mathrm{fmol} \mathrm{C}$ cell $^{-1} \mathrm{~d}^{-1}$ obtained by Reinthaler et al. (2006) for the meso- and bathypelagic realms of the eastern and western North Atlantic basin. Consequently, their estimated turnover times of 34 to $54 \mathrm{~d}$ are longer than the turnover times of 24 and $30 \mathrm{~d}$ obtained in the present study for the OMZ and $2000 \mathrm{~m}$ depth, respectively (Table 1). Moreover, Reinthaler et al. (2006) used a conversion factor of $3.1 \mathrm{~kg} \mathrm{C} \mathrm{mol}^{-1}$ Leu (assuming a 2-fold isotopic dilution), whereas we used $1.5 \mathrm{~kg} \mathrm{C} \mathrm{mol}{ }^{-1}$ Leu (assuming no isotopic dilution). If we recalculate their data with $1.5 \mathrm{~kg} \mathrm{C} \mathrm{mol}{ }^{-1} \mathrm{Leu}$, the cell-specific prokaryotic production would be even lower and, consequently, the turnover times longer, increasing the differences with our results even more. Hence, the variability in the metabolic rates between these 2 studies must be caused by factors other than the carbon-to-leucine conversion factors used to calculate prokaryotic production.

Differences in prokaryotic activity between the deep waters of the central North Atlantic and the eastern boundary region of the subtropical North Atlantic are likely caused by the greater supply of organic matter 
to prokaryotic communities closer to the continental margin. Arístegui et al. (2005) estimated an average prokaryotic growth rate of $0.13 \pm 0.02 \mathrm{~d}^{-1}$ for the mesopelagic zone of the Canary Current, which is in agreement with the growth rate obtained in the present study for the $200 \mathrm{~m}$ horizon $\left(0.14 \pm 0.02 \mathrm{~d}^{-1}\right)$ and the OMZ $\left(0.12 \pm 0.03 \mathrm{~d}^{-1}\right)$. Arístegui et al. (2005) concluded, after analyzing a set of metabolic indices, that prokaryotic communities in the mesopelagic zone are very active, acting as major sinks for organic carbon in the subtropical NE Atlantic Ocean.

\section{Prokaryotic assemblage variability}

One of the main goals of our study was to decipher patterns in distribution in bulk prokaryotic properties and assemblage structure linked to water mass characteristics and hydrographic regimes, particularly in the deep ocean. Previous studies using PCR-independent methods have identified and quantified the dominant bacterial groups in surface waters (Eilers et al. 2001, Fuchs et al. 2005); however, only rather rudimentary information is available on the abundance of the major bacterial groups in the meso- and bathypelagic zones using FISH (see 'Introduction'). In some of the surfacewater studies, minor differences in the proportion of major phylogenetic groups, but larger differences in the proportion of more specific groups such as SAR86, SAR11, SAR116 (Fuchs et al. 2005) and SAR202 (Morris et al. 2004), were found. Alonso-Sáez et al. (2007b), using CARD-FISH, found that bacterial assemblage structure in surface waters of the subtropical NE Atlantic was highly influenced by environmental factors, with a distinct community in the upwelling region different from the more oceanic waters. In the present study, we observed a large variability in the prokaryotic assemblage along the coast-ocean transect. At the DCM, the relative contributions of SAR11, marine Euryarchaeota Group II and marine Crenarchaeota Group I to DAPI-stained cells increased towards the open ocean, while Gammaproteobacteria, Roseobacter and Bacteroidetes were more abundant towards the upwelling region (Fig. 5), where bulk prokaryotic activity was generally higher (Fig. 4B,C). This is in agreement with other studies, which also report high contributions of the Bacteroidetes cluster to total prokaryotic abundance in upwelling systems (Fandino et al. 2001, Alonso-Sáez et al. 2007b). Roseobacter was also related previously to the presence of high phytoplankton biomass (González \& Moran 1997, Eilers et al. 2001), while the Gammaproteobacteria were associated with nutrient pulses (Eilers et al. 2000, AlonsoSáez et al. 2007b). SAR11 was the most abundant group in the DCM, as also described in previous stud- ies (Morris et al. 2002, Alonso-Sáez et al. 2007a). This cosmopolitan group represents $>50 \%$ of the prokaryotic abundance in the surface waters of the NW Sargasso Sea and $25 \%$ of the mesopelagic microbial assemblages (Morris et al. 2002), declining in its contribution to prokaryotic abundance with depth, however (Morris et al. 2004; our Fig. 5).

In the OMZ, the SAR11 clade showed a different distribution pattern than in the DCM, being more abundant at Stn 20 affected by upwelling AAIW (Fig. 5). Marine Crenarchaeota Group I and Bacteroidetes increased in their relative abundance towards the open ocean, with Stns 51 to 70 (affected by MSOW) exhibiting very similar community composition (Fig. 5). At $2000 \mathrm{~m}$ depth, no clear gradient in prokaryotic community composition was discernable, although Bacteroidetes and the marine Crenarchaeota Group I were more abundant in the more oceanic waters (Fig. 5). The estimated relative abundance of marine Euryarchaeota Group II (4 to $13 \%$ in the DCM and 6 to $20 \%$ in deep waters) is in agreement with the observations reported by Teira et al. (2006b) for the North Atlantic Ocean, where marine Euryarchaeota Group II ranged from $<10$ to $>30 \%$ in subsurface waters and $<15 \%$ of the total picoplankton community at the $100 \mathrm{~m}$ layer. While SAR11 decreased in relative abundance with depth, marine Crenarchaeota Group I increased with depth (Fig. 5). The highest relative abundance of marine Crenarchaeota Group I, Bacteroidetes and Gammaproteobacteria were found in the OMZ, except at Stn 20, where the OMZ was influenced by AAIW. Teira et al. (2006a) also found the highest absolute abundance of marine Crenarchaeota Group I (accounting for $>40 \%$ of DAPI-stained cells) in the OMZ of the North Atlantic. The increase of marine Crenarchaeota Group I and Gammaproteobacteria in the OMZ might be related to nitrification processes in the OMZ. Marine nitrification is mediated by 3 different groups of prokaryotes belonging to the Beta- and Gammaproteobacteria (Ward 2002), although recently, evidence has been accumulating that Crenarchaeota also contribute to marine nitrification (Könneke et al. 2005, Wuchter et al. 2006). It is noteworthy, however, that Wuchter et al. (2006) did not find any gammaproteobacterial amoA genes, a gene indicative for the potential to oxidize ammonia. Only betaproteobacterial and marine crenarchaeotal Group I.1a amoA genes were retrieved (Wuchter et al. 2006). It is worth noting that crenarchaeal amoA gene copy numbers determined by q-PCR dominated over betaproteobacterial amoA gene copy numbers throughout the North Atlantic mesopelagic waters (Wuchter et al. 2006). In soils, the copy numbers of crenarchaeal amoA genes also outnumber betaproteobacterial amoA genes (Leininger et al. 2006). Crenarchaeota oxidizing ammonia 
could play an important, previously unrecognized, role in the biogeochemical cycling of nitrogen in the ocean, although their actual nitrification rates in natural environments remain to be determined.

\section{Bacteria versus Archaea}

Recent reports on the distribution of Bacteria and Archaea in the oceans indicate that planktonic marine Crenarchaeota Group I increase in their relative contribution to prokaryotic abundance with depth, reaching cell numbers similar to or higher than those of Bacteria in the mesopelagic zone (Karner et al. 2001, Teira et al. 2006b). Marine Euryarchaeota Group II, the other major archaeal group, is, however, commonly more abundant in surface than deep waters (Massana et al. 2000, Karner et al. 2001, Church et al. 2003), comprising up to $10-30 \%$ of picoplankton abundance in subsurface waters (Herndl et al. 2005, Teira et al. 2006b). Some Euryarchaeota in surface waters harbor proteorhodopsin, a light-harvesting pigment that allows light to be used as an additional energy source, while deep-water Euryarchaeaota lack proteorhodopsin (Frigaard et al. 2006).

The fact that marine Crenarchaeota Group I increase in their relative abundance with depth while bacterial abundance decreases (e.g. Massana et al. 1997, Herndl et al. 2005, Teira et al. 2006a) suggests that they occupy different ecological niches, likely caused by environmental conditions and different substrate requirements. These different ecological niches, however, cannot be deciphered at the moment, as both marine Crenarchaeota Group I and Bacteria are capable of utilizing similar model substrates (Teira et al. 2006a, Kirchman et al. 2007). Our results show a relative increase with depth (Fig. 5) of both marine Crenarchaeota Group I and marine Euryarchaeota Group II, although absolute archaeal abundances were always higher at the DCM. In all cases the ratio of total Archaea:Bacteria was $\leq 1$ (average \pm SD: $0.24 \pm 0.08$ for the DCM, $0.82 \pm 0.11$ for the OMZ and $0.68 \pm 0.17$ for the $2000 \mathrm{~m}$ depth layer).

An even more pronounced trend in the distribution of Bacteria versus Archaea than over depth was observed laterally along the coast-offshore gradient in the DCM (Fig. 5). Although Archaea were always 2 to 7 times lower in abundance than Bacteria, the decrease in bacterial abundance from the upwelling region towards the open ocean coincided with a concomitant increase in Archaea as described by the equation: Bacteria (cells ml ${ }^{-1}$ ) $=0.61 \times$ Archaea $($ cells $\left.\mathrm{ml}^{-1}\right)-60255\left(\mathrm{R}^{2}=0.98, \mathrm{p}<0.00001\right)$. A similar, although less pronounced, contrasting abundance pattern of archaeal and bacterial abundance was found for the OMZ (data not shown). Marine Crenarchaeota Group I constituted $79 \%$ of the total abundance of Archaea in the OMZ, while in the DCM both archaeal groups contributed roughly equally. Lateral gradients in the relative abundance of Bacteria versus Archaea have not been reported thus far. The decrease in bulk leucine uptake along the coast-ocean gradient was positively related $\left(\mathrm{R}^{2}=0.72, \mathrm{n}=6\right)$ to the decrease in bacterial abundance in the DCM, and negatively related $\left(R^{2}=-0.76, n=6\right)$ to the increase in archaeal abundance. This suggests that most of the bulk prokaryotic heterotrophic production, as estimated by leucine incorporation, was due to bacterial activity. In addition, SAR11 was the most abundant prokaryotic group in the DCM, decreasing 2-fold from Stn 4 to Stn 70, although increasing in the relative contribution to prokaryotic abundance towards the oceanic stations. Thus, this group is probably the major contributor to the bulk prokaryotic metabolism in the open ocean's surface waters.

\section{CONCLUSIONS}

A high variability was observed in bulk prokaryotic abundance and metabolism, as well as in changes in community structure, in the surface waters from the NW Africa upwelling region towards the open ocean. This variability was comparable to the variability reported for ocean-basin studies. Bacteria (SAR11, Roseobacter, Gammaproteobacteria and Bacteroidetes) were relatively more abundant in coastal than in oceanic regions, in contrast to the distribution of marine Euryarchaeota Group II and marine Crenarchaeota Group I. SAR11 was mainly responsible for the surface-water variability in bulk prokaryotic abundance. Prokaryotic abundance decreased about 2 orders of magnitude from the surface to $2000 \mathrm{~m}$ deep waters, whereas prokaryotic production decreased by 3 orders of magnitude. Both archaeal groups contributed up to $50 \%$ to the total prokaryotic abundance in the dark ocean. AAIW exhibits lower prokaryotic activity than MSOW, presumably due to lower organic matter content of the AAIW. Prokaryotic growth rates in the deep ocean were considerably higher than those reported for the central Atlantic, but comparable to previous studies from the same region. This supports the view that prokaryotic communities in the deep waters of the subtropical NE Atlantic maintain higher metabolic rates than in the central Atlantic due to lateral input of organic matter from the continental margins.

Acknowledgements. Fieldwork was supported by the CONAFRICA (CTM2004-02319) and RODA (CTM 200406842-C03/MAR) projects. This is a contribution to the Mar- 
BEF European Network of Excellence funded by the European Union (GOCE-CT-2003-505446) and to EUR-OCEANS, a European Network of Excellence funded by the European Commission (6th Framework Programme, contract no. 511106). Financial support was provided by a PhD fellowship from the Spanish government to F.B. We thank the crew and other scientists aboard the RV 'BIO-Hesperides' for their help during the cruise. The authors thank 2 anonymous reviewers whose comments and suggestions helped improve the manuscript. This work is in partial fulfillment of the requirements for a PhD degree from the University of Las Palmas by F.B.

\section{LITERATURE CITED}

Alonso-Sáez L, Gasol JM, Arístegui J, Vilas JC, Vaqué D, Duarte CM, Agustí S (2007a) Large-scale variability in surface bacterial carbon demand and growth efficiency in the subtropical northeast Atlantic Ocean. Limnol Oceanogr 52:533-546

Alonso-Sáez L, Arístegui J, Pinhassi J, Gómez-Consarnau L and others (2007b) Bacterial assemblage structure and carbon metabolism along a productivity gradient in the NE Atlantic Ocean. Aquat Microb Ecol 46:43-53

Amann RI, Binder BJ, Olson RJ, Chisholm SW, Devereux R, Stahl DA (1990) Combination of 16S rRNA-targeted oligonucleotide probes with flow cytometry for analyzing mixed microbial populations. Appl Environ Microbiol 56: 1919-1925

Arístegui J, Montero MF (2005) Temporal and spatial changes in plankton respiration and biomass in the Canary Islands region: the effect of mesoscale variability. J Mar Syst 54: $65-82$

Arístegui J, Barton ED, Montero MF, García-Muñoz M, Escánez J (2003) Organic carbon distribution and water column respiration in the NW Africa-Canaries Coastal Transition Zone. Aquat Microb Ecol 33:289-301

Arístegui J, Duarte C, Gasol JM, Alonso-Sáez L (2005) Active mesopelagic prokaryotes support high respiration in the subtropical northeast Atlantic Ocean. Geophys Res Lett 32:L03608, doi:10.1029/2004GL021863

Azam F, Fenchel T, Field JG, Gray JS, Meyer-Reil LA, Thingstad $F$ (1982) The ecological role of water column microbes in the sea. Mar Ecol Prog Ser 10:257-263

Barton ED, Arístegui J, Tett P, Navarro-Pérez E (2004) Variability in the Canary Islands area of filament-eddy exchanges. Prog Oceanogr 62:71-94

Church MJ, De Long EF, Ducklow HW, Karner MB, Preston CM, Karl DM (2003) Abundance and distribution of planktonic Archaea and Bacteria in the waters west of the Antarctic Peninsula. Limnol Oceanogr 48:1893-1902

Cottrell MT, Kirchman DL (2000) Natural assemblages of marine Proteobacteria and members of the CytophagaFlavobacter cluster consuming low- and high-molecularweight dissolved organic matter. Appl Environ Microbiol 66:1692-1697

Daims H, Bruhl A, Amann R, Schleifer KH, Wagner M (1999) The domain-specific probe EUB338 is insufficient for the detection of all bacteria: development and evaluation of a more comprehensive probe set. Syst Appl Microbiol 22: 434-444

DeLong EF, Wu KY, Prezelin BB, Jovine RVM (1994) High abundance of Archaea in Antarctic marine picoplankton. Nature 371:695-697

Eilers H, Pernthaler J, Amann R (2000) Succession of pelagic marine bacteria during enrichment: a close look at cultivation-induced shifts. Appl Environ Microbiol 66:
$4634-4640$

Eilers H, Pernthaler J, Peplies J, Glöckner FO, Gerdts G, Amann R (2001) Isolation of novel pelagic bacteria from the German Bight and their seasonal contributions to surface picoplankton. Appl Environ Microbiol 67:5134-5142

Fandino LB, Riemann L, Steward GF, Long RA, Azam F (2001) Variations in bacterial community structure during a dinoflagellate bloom analyzed by DGGE and 16S rDNA sequencing. Aquat Microb Ecol 23:119-130

Frigaard NU, Martinez A, Mincer TJ, DeLong EF (2006) Proteorhodopsin lateral gene transfer between marine planktonic Bacteria and Archaea. Nature 439:847-850

Fuchs BM, Woebken D, Zubkov MV, Burkill P, Amann R (2005) Molecular identification of picoplankton populations in contrasting waters of the Arabian Sea. Aquat Microb Ecol 39:145-157

Fukuda R, Ogawa H, Nagata T, Koike I (1998) Direct determination of carbon and nitrogen content of natural bacteria assemblages in marine environments. Appl Environ Microbiol 64:3352-3358

Gasol JM, Del Giorgio PA, Duarte CM (1997) Biomass distribution in marine planktonic communities. Limnol Oceanogr 42:1353-1363

Gasol JM, Zweifel UL, Peters F, Fuhrman JA, Hagström ^̊ (1999) Significance of size and nucleic acid content in heterogeneity as measured by flow cytometry in natural planktonic bacteria. Appl Environ Microbiol 65:4475-4483

Giovannoni SJ, Rappé MS (2000) Evolution, diversity and molecular ecology of marine prokaryotes. In: Kirchman DL (ed) Microbial ecology of the oceans. Wiley-Liss, New York, p 47-85

Giovannoni SJ, Britschgi TB, Moyer CL, Field KG (1990) Genetic diversity in Sargasso Sea bacterioplankton. Nature 345:60-63

Gleason HA (1926) The individualistic concept of the plant association. Bull Torrey Bot Club 53:7-26

González JM, Moran MA (1997) Numerical dominance of a group of marine bacteria in the alpha-subclass of the class Proteobacteria in coastal seawater. Appl Environ Microbiol 63:4237-4242

Hernández-Guerra A, López-Laatzen F, Machín F, De Armas D, Pelegrí JL (2001) Water masses, circulation and transport in the eastern boundary current of the North Atlantic subtropical gyre. Sci Mar 65(Suppl 1):177-186

Herndl GJ, Reinthaler T, Teira E, Van Aken H, Veth C, Pernthaler A, Pernthaler J (2005) Contribution of Archaea to total prokaryotic production in the deep Atlantic Ocean. Appl Environ Microbiol 71:2303-2309

Hewson I, Steele JA, Capone DG, Fuhrman JA (2006) Remarkable heterogeneity in meso- and bathypelagic bacterioplankton assemblage composition. Limnol Oceanogr 51:1274-1283

Hoppe HG, Gocke K, Koppe R, Kraus G (2006) Changing bacterioplankton growth characteristics on a large spatial scale: oligotrophic versus mesotrophic ocean. Mar Ecol Prog Ser 323:21-33

Karner MB, De Long EF, Karl DM (2001) Archaeal dominance in the mesopelagic zone of the Pacific Ocean. Nature 409:507-510

Kirchman DL (2002) Calculating microbial growth rates from data on production and standing stocks. Mar Ecol Prog Ser 233:303-306

Kirchman DL, Elifantz H, Dittel AI, Malmstrom RR, Cottrell MT (2007) Standing stock and activity of Archaea and Bacteria in the western Arctic Ocean. Limnol Oceanogr 52:495-507

Könneke $\mathrm{M}$, Bernhard $\mathrm{AE}$, de la Torre JR, Walker $\mathrm{CB}_{\text {, }}$ 
Waterbury JB, Stahl DA (2005) Isolation of an autotrophic ammonia-oxidizing marine archaeon. Nature 437:543-546

Leininger S, Ulrich $\mathrm{T}$, Schloter $\mathrm{M}$, Schwark L and others (2006) Archaea predominate among ammonia-oxidizing prokaryotes in soils. Nature 442:806-809

Malmstrom RR, Kiene RP, Cottrell MT, Kirchman DL (2004a) Contribution of SAR11 bacteria to dissolved dimethylsulfoniopropionate and amino acid uptake in the North Atlantic Ocean. Appl Environ Microbiol 70:4129-4135

Malmstrom RR, Kiene RP, Kirchman DL (2004b) Identification and enumeration of bacteria assimilating dimethylsulfoniopropionate (DMSP) in the North Atlantic and Gulf of Mexico. Limnol Oceanogr 49:597-606

Manz W, Amann R, Ludwig W, Wagner M, Schleifer KH (1992) Phylogenetic oligodeoxynucleotide probes for the major subclasses of Proteobacteria-problems and solutions. Syst Appl Microbiol 15:593-600

Massana R, Murray AE, Preston CM, DeLong EF (1997) Vertical distribution and phylogenetic characterization of marine planktonic Archaea in the Santa Barbara Channel. Appl Environ Microbiol 63:50-56

Massana R, Taylor LT, Murray AE, Wu KY, Jeffrey WH, De Long EF (1998) Vertical distribution and temporal variation of marine planktonic archaea in the Gerlache Strait, Antarctica, during early spring. Limnol Oceanogr 43: 607-617

Massana R, DeLong EF, Pedros-Alió C (2000) A few cosmopolitan phylotypes dominate planktonic archaeal assemblages in widely different oceanic provinces. Appl Environ Microbiol 66:1777-1787

Morris RM, Rappé MS, Connon SA, Vergin KL, Slebold WA, Carlson CA, Giovanonni SJ (2002) SAR11 clade dominates ocean surface bacterioplankton communities. Nature 420: 806-810

Morris RM, Rappe MS, Urbach E, Connon SA, Giovannoni SJ (2004) Prevalence of the chloroflexi-related SAR202 bacterioplankton cluster throughout the mesopelagic zone and deep ocean. Appl Environ Microbiol 70:2836-2842

Mullins TD, Britschgi TB, Krest RL, Giovannoni SJ (1995) Genetic comparisons reveal the same unknown bacterial

Editorial responsibility: Jed Fuhrman,

Los Angeles, California, USA lineages in Atlantic and Pacific bacterioplankton communities. Limnol Oceanogr 40:148-158

Pedrós-Alió C (2006) Marine microbial diversity: can it be determined? Trends Microbiol 14:257-263

Pernthaler A, Pernthaler J, Amann R (2002) Fluorescence in situ hybridization and catalyzed reporter deposition for the identification of marine bacteria. Appl Environ Microbiol 68:3094-3101

Rappe MS, Vergin K, Giovannoni SJ (2000) Phylogenetic comparisons of a coastal bacterioplankton community with its counterparts in open ocean and freshwater systems. FEMS Microbiol Ecol 33:219-232

Reinthaler T, Van Aken H, Veth C, Lebaron P and others (2006) Prokaryotic respiration and production in the mesoand bathypelagic realm of the eastern and western North Atlantic basin. Limnol Oceanogr 51:1262-1273

Simon M, Azam F (1989) Protein content and protein synthesis rates of planktonic marine bacteria. Mar Ecol Prog Ser 51:201-213

Smith DC, Azam F (1992) A simple, economical method for measuring bacterial protein synthesis rates in seawater using ${ }^{3}$ H-leucine. Mar Microb Food Webs 6:107-114

Teira E, Reinthaler T, Pernthaler A, Pernthaler J, Herndl G (2004) Combining catalyzed reported deposition-fluorescence in situ hybridization and microautoradiography to detect substrate utilization by Bacteria and Archaea in the deep ocean. Appl Environ Microbiol 70:4411-4414

Teira E, Van Aken HM, Veth C, Herndl GJ (2006a) Archaeal uptake of enantiomeric amino acids in meso- and bathypelagic waters of the North Atlantic. Limnol Oceanogr 51:60-69

Teira E, Lebaron P, Van Aken HM, Herndl GJ (2006b) Distribution and activity of Bacteria and Archaea in the deep water masses of the North Atlantic. Limnol Oceanogr 51:2131-2144

Ward BB (2002) Nitrification in aquatic systems. In: Capone DA (ed) Encyclopedia of environmental microbiology. Wiley, New York, p 2144-2167

Wuchter C, Abbas B, Coolen MJL, Herfort L and others (2006) Archaeal nitrification in the ocean. Proc Natl Acad Sci USA 103:12317-12322

Submitted: June 1, 2007; Accepted: October 1, 2007

Proofs received from author(s): December 1, 2007 